\title{
ANALISIS KELAYAKAN USAHATANI SEMANGKA (STUDI KASUS DI DESA JANGKAR, KECAMATAN JANGKAR, KABUPATEN SITUBONDO)
}

\author{
Edi Musleh 1), Andina Mayangsari 2*) \\ Fakultas Pertanian, Universitas Abdurachman Saleh Situbondo \\ *Email Korespondensi : anmajas66@gmail.com
}

\begin{abstract}
Abstrak
Tujuan penelitian ini adalah untuk mengetahui pendapatan terhadap hasil produksi pada usahatani semangka Desa Jangkar Kecamatan Jangkar Kabupaten Situbondo dan untuk mengetahui tingkat efesiensi terhadap produksi pada usahatani semangka Desa Jangkar Kecamatan Jangkar Kabupaten Situbondo. Metode penelitian yang gunakan dalam penelitian ini adalah metode kuantitatif yang diperkuat dengan metode kualitatif deskriptif dengan pendekatan survey dan Analisis datanya menggunakan R/C Ratio. Berdasarkan dari hasil penelitian yang telah dilakukan dan telah diuraikan sebelumnya, maka dapat ditarik beberapa kesimpulan dari keseluruhan hasil penelitian yaitu rata-rata pendapatan usahatani semangka dalam satu musim tanam di Desa Jangkar Kecamatan Jangkar Kabupaten Situbondo sebesar Rp 9.089.470. Hasil tingkat efesiensi terhadap produksi pada usahatani semangka Desa Jangkar Kecamatan Jangkar Kabupaten Situbondo yaitu 2,080, lebih besar dari 1 (satu) maka usahatani semangka efisien
\end{abstract}

Kata kunci : pendapatan, usahatani semangka

\begin{abstract}
The purpose of this study is to determine the income of the production on watermelon farming in Jangkar Village, Jangkar District, Situbondo Regency and to determine the level of efficiency of production on watermelon farming in Jangkar Village, Jangkar District, Situbondo Regency. The research method used in this study is quantitative method that is reinforced by descriptive qualitative method with survey approach. The data analysis wasusing R/C Ratio. Based on the result, some conclusions can be drawn, namely the average income of watermelon farming in one planting season in the Jangkar Village, Jangkar District, Situbondo Regency is $R p$ 9,089,470. The result of the analysis shows that the level of production efficiency on watermelon farming in Jangkar Village, JangkarDistrict, Situbondo Regency is 2.080, higher than 1 (one). Then, it can be concluded thatthe watermelon farming is efficient
\end{abstract}

Keywords : income, watermelon farming

\section{PENDAHULUAN}

Indonesia merupakan negara agraris yang tentunya sebagian besar wilayahnya terdiri dari lahan pertanian dan sebagian besar penduduknya bermata pencaharian sebagai petani. Sektor pertanian terus dituntut berperan dalam perekonomian nasional melalui pembentukan Produk Domestik Bruto (PDB), perolehan devisa, penyediaan pangan dan bahan baku industri, pengentasan kemiskinan, penyediaan lapangan pekerjaan dan peningkatan pendapatan masyarakat. Selain kontribusi langsung, sektor pertanian juga memiliki kontribusi yang tidak langsung berupa efek pengganda (multiplier effect) yaitu keterkaitan input- output antar industri dan investasi, dampak pengganda tersebut relatif lebih besar sehingga sektor pertanian layak dijadikan sektor andalan dalam perekonomian Indonesia. Sektor pertanian juga menjadi andalan dalam 
mengembangkan kegiatan ekonomi pedesaan melalui pengembangan usaha berbasis pertanian.

Terdapat beberapa tempat yang membudidayakan semangka di daerah Jawa Timur dan ada beberapa jenis yang diminati para petani atau konsumen. Di di Jawa Timur yang cocok dibudidayakan dibagi menjadi 2 kelompok yaitu: Semangka Lokal dan Semangka Hibrida Impor (dari hasil silangan Hibridasi) yang mempunyai keunggulan tersendiri. Semangka tersebut diklasifikasikan menurut benih murni negara asalnya: benih Yamato, Sugar Suika, Cream Suika dan lainnya. Tanaman semangka dibudidayakan untuk dimanfaatkan sebagai buah segar, tetapi ada yang memanfaatkan daun dan buah semangka muda untuk bahan sayur-mayur.

Tanaman semangka termasuk salah satu jenis tanaman buah-buahan semusim yang mempunyai arti penting bagi perkembangan sosial ekonomi rumah tangga maupun negara. Pengembangan budidaya komoditas ini mempunyai prospek cerah karena dapat mendukung upaya peningkatan pendapatan petani, pengentasan kemiskinan, perbaikan gizi masyarakat, perluasan kesempatan kerja, pengurangan impor dan peningkatan ekspor nonmigas (Rukmana, 2005).

Dari penanaman semangka tersebut dapat memberikan nilai tambah yang lumayan bagi petani kecil, terutama petani yang biasanya hanya menanam semangka. Hal ini selaras dengan kebijaksanaan pemerintah dalam pengembangan tanaman hortikultura. Kebijaksanaan pemerintah dalam pengembangan tanaman hortikultura di Indonesia antara lain bertujuan untuk:

1. Meningkatkan pendapatan petani melalui peningkatan produksi dan kualitas hortikultura.

2. Mendukung pengentasan kemiskinan dan pemenuhan gizi di pedesaan.

3. Meningkatkan penggunaan ilmu pengetahuan dan teknologi baru di bidang hortikultura.

4. Mencukupi kebutuhan produk hortikultura di dalam negeri dan meningkatkan ekspor hortikultura (Prajnanta, 2003).

Semangka mempunyai daya tarik khusus karena buahnya yang berasa segar, banyak mengandung air lebih kurang 92 persen. Walaupun nilai gizinya termasuk rendah yaitu hanya mengandung 7 persen karbohidrat dalam bentuk gula dan kandungan vitamin dan mineralnya pun tergolong rendah, namun buah ini diminati konsumen karena rasanya yang segar.

Situbondo sebelah timur banyak petani menanam semangka. Salah satu tanaman buah-buahan yang banyak dikonsumsi oleh masyarakat adalah semangka. Tanaman semangka merupakan salah satu tanaman buah-buahan semusim selain melon dan blewah yang berumur kurang dari satu tahun, dapat berbentuk rumpun, menjalar dan berbatang lunak. Perkembangan luas panen dan produksi tanaman buah-buahan semusim menurut kabupaten atau kota di Situbondo hal ini menunjukkan bahwa produksi dan luas panen terbesar untuk tanaman buah-buahan semusim di Situbondo pada tahun 2017 adalah buah semangka yang ada di Kabupaten Situbondo, dengan produksi sebesar $12.091 \mathrm{ku}$ dan luas panen 405 ha. Perkembangan luas panen dan produksi tanaman buah-buahan semusim di Situbondo dari tahun 2014 - 2017 terlihat berfluktuasi baik dari buah melon, semangka maupun blewah. Dilihat dari perkembangannya, luas areal dan produksi tertinggi pertama adalah semangka. Besarnya produksi tersebut disebabkan oleh kondisi alam daerah yang mendukung untuk dikembangkannya tanaman semangka, baik dari segi iklim maupun kondisi tanah yang mendukung untuk pertumbuhan buah semangka tersebut.

Daya tarik budidaya semangka bagi petani terletak pada nilai ekonomisnya yang tinggi. Beberapa kelebihan usahatani semangka diantaranya adalah berumur relatif singkat hanya sekitar 70 - 80 hari, dapat dijadikan tanaman penyela di lahan sawah pada 
musim kemarau, mudah dipraktekkan para petani dengan cara biasa (konvensional) maupun semi intensif, serta memberikan keuntungan yang memadai (Rukmana, 2005).

Berdasarkan data dan informasi yang diperoleh dari para petani semangka, hasil panen yang maksimal hanya $700 \mathrm{~kg}$ per rante. Penyebab tidak bisa maksimalnya hasil panen petani semangka dikarenakan para petani belum bertanam secara intensif dan masih mengandalkan metode tanam yang konvensional, padahal faktor irigasi dan kesuburan tanah sangat memadai di daerah Situbondo.

Walaupun petani semangka di daerah penelitian masih mengandalkan metode tanam yang konvensional dan belum memuaskan namun usahatani ini tetap berjalan. Keberlanjutan usahatani ini ditentukan oleh gambaran secara finansial. Suatu usahatani dapat bertahan apabila jumlah penerimaan lebih besar daripada seluruh biaya-biaya yang dikeluarkan. maka peneliti tertarik untuk mengetahui apakah usahatani semangka di daerah penelitian layak untuk diusahakan atau tidak.

\section{METODE PENELITIAN \\ Metode penelitian}

Penelitian pada dasarnya untuk menunjukan kebenaran dan pemecahan masalah atas apa yang diteliti untuk mencapai tujuan tersebut, dilakukan suatu metode yang tepat dan relevan untuk tujuan yang diteliti. Pengertian Metode Penelitian menurut Sugiyono (2013) adalah: "Metode penelitian diartikan sebagai cara ilmiah untuk mendapatkan data dengan tujuan dan kegunaan tertentu".

Metode penelitian yang penulis gunakan dalam penelitian ini adalah metode kuantitatif yang diperkuat dengan metode kualitatif deskriptif dengan pendekatan survey. Metode penelitian survey digunakan untuk mendapatkan data dari tempat tertentu yang alamiah (bukan buatan), tetapi peneliti melakukan perlakuan dalam pengumpulan data.

\section{Metode Penentuan Sampel}

Sampel merupakan bagian dari jumlah dan karakterisitik yang dimiliki oleh suatu populasi yang akan diteliti. Penentuan sampel dalam penelitian ini dilakukan dengan jenis Non Probability Sampling. Menurut Sugiyono (2013) nonprobability sampling adalah teknik yang tidak memberi peluang/kesempatan yang sama bagi setiap unsur atau anggota populasi untuk dipilih menjadi sampel. Teknik Non Probability Sampling yang dipilih yaitu dengan Sampling Jenuh (sensus) yaitu metode penarikan sampel bila semua anggota populasi dijadikan sebagai sampel. Teknik pengambilan sampel dengan menggunakan metode sampel jenuh. Metode sampel jenuh adalah teknik penentuan sampel bila semua anggota populasi digunakan menjadi sampel. Dalam penelitian ini sampel yang akan diambil adalah semua petani semangka yang ada di Desa Jangkar yang berjumlah 30 orang.

\section{Metode pengumpulan data} berikut:

Metode pengumpulan data yang digunakan dalam penelitian ini adalah sebagai

a. Kuesioner (Angket)

Menurut Sugiyono, (2013), metode kuesioner merupakan teknik pengumpulan data yang dilakukan dengan cara memberi seperangkat pertanyaan atau pernyataan tertulis kepada responden untuk dijawab dan Dengan kuesioner dapat mengetahui keadaan atau data pribadipetani. Data yang ingin diperoleh peneliti yakni dengan cara memberi angket kepada petani semangka yang ada di Desa Jangkar Kecamatan Jangkar Kabupaten Situbondo. Bentuk kuesioner yang digunakan sebagai metode utama untuk mengetahui pengaruh luas lahan, jumlah tenaga kerja, modal, dan teknologi terhadap produksi 
usahatani semangka yang ada di Desa Jangkar Kecamatan Jangkar Kabupaten Situbondo.

b. Metode Wawancara

Metode wawancara adalah proses memperoleh keterangan untuk tujuan penelitian dengan cara tanya jawab sambil bertatap muka antara pewawancara dengan responden atau orang yang diwawancara. Data diperoleh dengan melakukan wawancara dengan pihak petani semangka yang ada di Desa Jangkar. untuk mendapatkan informasi yang diinginkan.

\section{c. Dokumentasi}

Merupakan metode pengumpulan data dengan cara mencari data mengenai hal-hal atau variabel yang berupa catatan, transkip, buku, surat kabar, majalah, prasasti, notulen, rapat, agenda, dan sebagainya, Arikunto (2010). Dokumen yang digunakan peneliti disini berupa foto, gambar, serta data-data dari petani semangka yang ada di Desa Jangkar untuk memudahkan peneliti untuk memperoleh informasi yang diperlukaan selama proses penelitian berlangsung.

\section{Analisis Data}

a. Pendapatan

Untuk mengetahui keakuratan data maka perlu dilakukan beberapa pengujian, diantaranya untuk dapat mengetahui pendapatan yang diperoleh petani, terlebih dahulu mencari total biaya lalu penerimaan usahatani. Total penerimaan usahatani adalah perkalian antara produksi dan harga jual.

1. Perhitungan Biaya

Rumus total biaya sebagai berikut:

$$
\mathrm{TC}=\mathrm{TFC}+\mathrm{TVC}
$$

Katerangan :

$\mathrm{TC}=$ Total Biaya (total cost)

$\mathrm{TFC}=$ total biaya tetap (total fix cors)

$\mathrm{TVC}=$ total biaya variabel (total variable cors)

\section{Penerimaan}

Kemudian untuk mencari penerimaan adalah sebagai berikut

$$
\mathrm{TR}=\mathrm{Y} \mathrm{x} \text { Py }
$$

Keterangan :

$\mathrm{TR}=$ Penerimaan usahatani Semangka (RP)

$\mathrm{Y} \quad=$ Produksi yang diperoleh dalam usahatani Semangka (Kg)

$\mathrm{Py}=$ Harga produksi Semangka $(\mathrm{Rp} / \mathrm{Kg})$

Menurut Soekartawi (2006), perhitungan pendapatan usaha dapat dirumuskan sebagai berikut :

$$
\mathrm{n}=\mathrm{TR}-\mathrm{TC}
$$

Keterangan :

$\mathrm{n} \quad=$ Pendapatan

$\mathrm{TR}=$ Total Revenue (total Penerimaan)

$\mathrm{TC}=$ Total Cost (Total Biaya)

\section{b. Analisis R/C Ratio}

Analisis R/C Ratio adalah suatu analisis yang digunakan untuk mengetahui keuntungan yang relatif pada usahatani. Rumus R/C Ratio Supartama et al. (2013) yaitu: rumus Efisiensi R/C Ratio sebagai berikut:

$$
\mathrm{R} / \mathrm{C} \text { Rasio }=\frac{T R}{T C}
$$


Dimana :

$\mathrm{R} / \mathrm{C}$ Ratio = kelayakan atau efisiensi usaha

$\mathrm{TC}=$ Total Penerimaan

TR = Total Biaya

Setelah selesai dilakukan perhitungan maka dapat dilakukan keputusan.

Kriteria keputusan :

$\mathrm{R} / \mathrm{C}>1=$ Efisien ata menguntungkan.

$\mathrm{R} / \mathrm{C}=1=$ Impas.

$\mathrm{R} / \mathrm{C}<1=$ tidak efesien atau rugi

\section{HASIL DAN PEMBAHASAN}

\section{Penerimaan}

Rata-rata penerimaan usahatani semangka dihitung dengan mengalikan rata-rata jumlah produksi semangka dengan rata-rata harga semangka perkilogram. Rata-rata roduksi dan penerimaan usahatani semangka dalam satu musim tanam di Desa Jangkar Kecamatan Jangkar Kabupaten Situbodo menunjukkan bahwa rata-rata penerimaan usahatani semangka diperoleh dari rata-rata harga semangka sebesar Rp 2.000 dikali dengan rata-rata produksi semangka sebesar $8.750 \mathrm{Kg}$, maka diperoleh hasil rata- rata penerimaan sebesar Rp 17.500.000. Besar kecilnya penerimaan yang diterima petani tergantung dengan banyak sedikitnya hasil panen semangka dan harga yang berlaku saat itu.

\section{Biaya Produksi}

Biaya sarana produksi adalah biaya yang digunakan dalam usahatani semangka. Biaya sarana produksi usahatani semangka meliputi biaya pembelian benih, pupuk, dan pestisida. Besarnya biaya sarana produksi untuk satu kali musim tanam yaitu bulan April sampai dengan bulan Juni 2018 menunjukkan bahwa total rata-rata biaya usahatani semangka adalah Rp 5.433.500 per musim tanam dengan rata-rata luas lahan 0,49 Ha. Total sarana produksi usahatani semangka yaitu pembelian pupuk NPK sebesar 1.552.500. Penggunaan pupuk NPK sangat berpengaruh terhadap pertumbuhan semangka di Desa Jangkar. Petani semangka menggunakan pupuk kompos untuk pengikat air dalam tanah, pupuk NPK, dan pupuk ponska untuk media tanam semangka.

\section{Tenaga Kerja}

Tenaga kerja mempunyai peranan penting dalam usahatani semangka. Jumlah jam kerja pada usahatani semangka di Desa Jangkar adalah 6 jam dalam 1 hari. Tenaga kerja dalam usahatani semangka. Rata-rata penggunaan tenaga kerja usahatani semangka di Desa Jangkar menunjukkan bahwa rata-rata penggunaan tenaga kerja yang terbesar adalah sebesar Rp 1.877.000 dengan rata-rata 1 HOK. Rata-rata penggunaan tenaga kerja adalah pengolahan lahan sebesar Rp 51.000 dengan rata-rata 1 HOK. Rata-rata penggunaan tenaga kerja yang terbesar adalah penyiraman sebesar Rp 1.329.000 dengan rata-rata 31,7 HOK.

\section{Total Biaya}

Total biaya usahatani semangka dihitung dengan menjumlah rata-rata biaya tetap dan total biaya usahatani semangka dalam satu musim tanam di Desa Jangkar Kecamatan Jangkar Kabupaten Situbondo menunjukkan bahwa rata-rata biaya tetap usahatani semangka diperoleh sebesar Rp 1.100.030 dan nilai biaya variabel dengan jumlah Rp 7.310.500 sedangkan total biaya dengan sebesar Rp 8.410.530. 


\section{Pendapatan}

Pendapatan bersih (net farm income) merupakan hasil pengurangan dari total penerimaan dengan total pengeluaran. Pendapatan bersih merupakan imbalan bagi petani terhadap penggunaan seluruh faktor produksi. Pendapatan usahatani semangka sebesar Rp. 9.089.470, semakin besar pendapatan bersih usahatani maka dapat dikatakan kinerja usahatani tersebut semakin baik. Sumber modal juga berpengaruh terhadap penghasilan bersih usahatani (net farm earning) karena menentukan besarnya nilai bunga.

Nilai bunga dihitung berdasarkan persentase bunga dikalikan total pengeluaran. Persentase bunga ditentukan berdasarkan sumber modal pinjaman. Usahatani semangka di Desa Jangkar, semua petani tidak melakukan pinjaman untuk modal usahatani yang dilakukan.

Pendapatan usahatani semangka yang diperoleh sebesar $\mathrm{Rp}$ 9.089.470, semakin besar penghasilan bersih usahatani maka seluruh sumberdaya keluarga yang digunakan akan memperoleh imbalan yang semakin besar. Rata-rata imbalan bagi modal petani (return to farm equity capital) diperoleh dengan mengurangkan nilai kerja keluarga dari penghasilan bersih usahatani. Imbalan bagi modal petani yang diperoleh nilainya sama dengan imbalan bagi total modal. Hal ini dipengaruhi oleh semua modal usahatani yang digunakan oleh petani semangka merupakan modal sendiri. Penggunaan tenaga kerja dalam keluarga yang semakin banyak dapat diindikasikan bahwa usahatani tersebut masih mempunyai skala usaha relatif kecil yang dalam hal ini berhubungan erat dengan luasan lahan. Luasan lahan mempengaruhi keterjangkauan pekerjaan yang dapat dilakukan oleh petani, sehingga semakin luas lahan yang digunakan maka kecenderungan petani memberdayakan tenaga kerja lebih banyak.

\section{Kelayakan Usahatani}

Total biaya sebesar Rp. 8.410.530. dimana menunjukkan bahwa total biaya pada usahatani semangka akan membutuhkan modal sebesar Rp.

8.410.530 dalam satu kali tanam.

Pendapatan menunjukkan bahwa pada rata rata penerimaan petani pemilik $\mathrm{Rp}$ 17.500.000,- perbulan. Dengan biaya totalnya Rp 8,410.530,- perbulan dan pendapatan bersih yang diterima oleh petani semangka sebesar Rp.9.089.470,-perbulan. Pendapatan yang diperoleh seorang petani petani semangka tergatung banyaknya produksi semangka yang dihasilkan.

Hasil dari perhitungan R/C Ratio yaitu 2,080. Pengambilan keputusan berdasarkan pada R/C Ratio > 1, maka usahatani yang dilakukan layak. Dikatakan layak berarti petani di desa Jangkar usahatani semangka sangat menguntungkan dan bisa menanam lagi semangka pada tahun depan.

\section{KESIMPULAN}

Berdasarkan dari hasil penelitian yang telah dilakukan dan telah diuraikan sebelumnya, maka dapat ditarik beberapa kesimpulan dari keseluruhan hasil penelitian yaitu sebagai berikut:

1. Rata-rata pendapatan usahatani semangka dalam satu musim tanam di Desa Jangkar Kecamatan Jangkar Kabupaten Situbondo sebesar Rp 9.089.470.

2. Hasil tingkat efesiensi terhadap produksi pada usahatani semangka Desa Jangkar Kecamatan Jangkar Kabupaten Situbondo yaitu 2,080, lebih besar dari 1 (satu) maka usahatani semangka efisien. 


\section{REFERENSI}

Anonimous. 2012. Manfaat Buah Semangka. http://manfaat dan kandungan. blogspot.com

Arikunto, Suharsimi. 2006. Prosedur Penelitian (Suatu Pendekatan Praktik) : Suatu Pendekatan Praktek. Jakarta : Rineka Cipta.

Astutiningsih. 2009. Analisis pendapatan usahatani semangka (Citrullus vulgaris) di Kabupaten Sragen. Skripsi. Fakultas Pertanian. Universitas Sebelas Maret. Surakarta

Damayanti, Mia Nur. 2009. Kajian Pelaksanaan Kemitraan dalam Meningkatkan Pendapatan Antara Petani Semangka di Kabupaten Kebumen Jawa Tengah dengan CV. Bimandiri. IPB Press. Bogor.

Daniel Mohar. 2004. Pengantar Ekonomi pertanian. Jakarta: PT Bumi Aksara. 